\title{
OSTEOPOROSIS AND THE DURATION OF COCA·COLA CONSUMPTION RELATIONSHIP IN FEMALE ALBINO RATS
}

\author{
$\mathcal{B} \mathcal{Y}$ \\ Hanaa M. Serag \\ Department of Zoology, Faculty of Sciences, Mansoura University, Mansoura, Egypt.
}

\begin{abstract}
Coca-cola beverage is one of the risk factors resulting in calcium deficiencies and an increased risk of osteoporosis in rats. The objective of this study is the comparing between five and seven months of coca-cola consumption on osteoporosis markers. The obtained data suggested that orally coca-cola consumption $(5 \mathrm{ml} / \mathrm{Kg} /$ day) cause a significant increase in minerals (calcium and phosphorus) level, in both serum and urine while a significant decrease in the level of these minerals in bone was recorded specially in seven months rats group. At the same time, significant increases in serum and urine creatinine, urea and creatinine ratio as well as parathyroid hormone level, while a decrease in the level of calcitonine as well as in the total protein content were observed. In addition, a significant increase in the level of bone marker enzymes (alkaline and acid phosphatase) activity was recorded, indicating an increase in bone turnover rate. A significant increase was observed in femur water content in rats received cocacola, meanwhile, bone mineral density was significantly decreased. All these parameters are more pronounced at seven months group than those of five months only. Thus, it was concluded that the long-term consumption of coca-cola is strongly associated with the development of osteoporosis evidenced by the occurred changes in the estimated bone marker parameters.
\end{abstract}

Keywords: osteoporosis, coca-cola, bone markers.

\section{INTRODUCTION}

Consumption of soft drinks can lead to numerous health problems like osteoporosis, diabetes mellitus, tooth decay, heart disease, and neurological disorders (James et al., 2004, Bassiouny and Yang 2005). A number of risk factors may negatively affect bone metabolism and predispose to fracture, including the excessive consumption of carbonated beverages (Root, 2002 and Goulding, 2007). Epidemiological studies showing that increased cola beverage intake is associated with reduced bone 
mineral density, increased bone fracture risk at any age and an increased risk of osteoporosis later in life (Wyshak and Frisch, 1994). With aging, osteoporosis and related fractures are the major public health problems, the lifetime risk of fracture exceeds $40 \%$ for women and $13 \%$ for men (Kanis, 1994). Numerous dietary behaviors act as important factor for the loss of bone mineral density (BMD) that are associated with osteoporosis (Tucker, 2003). Soft drink consumption that increased in recent years has been found to be associated with low BMD and fractures with aging (Wyshak, 2000; Whiting et al.,2001 and Gartl and et al., 2003). The high phosphate and high caffeine in colas may result in an increased acid load in the body, which influence the calcium/phosphorous ratio and bone mineral density (Ogor et al., 2007). Soft drinks rich with caffeine, phosphoric acid, and fructose were shown to interfere with calcium absorption and contribute to imbalances that lead to additional loss of calcium (Amato et al., 1998, Milne and Nielsen, 2000 and Rapuri et al., 2001). Caffeine also increases free fatty acids and triacyl glycerol and is known to produce hyperlipidemia and increase the liver enzymes (Bobbi et al., 1984). Bone mineral density with daily soft drink intake in women was lower than that of non-consumers (Jean and Murray, 2003).

Therefore, the present study was carried out to clarify the relation between the duration of coca cola consumption and the osteoporosis associated with low bone mineral density in female rats.

\section{MATERIAL AND METHODS}

\section{Material:}

This study was performed on adult female albino rats (Rattus rattus) initially weighing $120 \pm 10 \mathrm{~g}$. Rats were obtained from the institute of Ophthalmic Disease Research, Cairo. They were housed in stainless steel cages within an air conditioned animal house at $23^{\circ} \mathrm{C}$. Rats were fed adequate standard diet and allowed water ad libitum and kept under normal laboratory conditions through the whole experimental work.

\section{Coca-cola beverage doses and routs of} administration:

Coca-cola beverage was purchased from local supermarket and was orally administered to rats at a daily dose of $5 \mathrm{ml} /$ $\mathrm{Kg} /$ day for five and seven months according to Kondal and Garg (2003).

\section{Methods :}

\section{1-Animal grouping:}

Animals were randomly divided into three groups, each with six rats as follows:

Group 1: Rats of this group served as a control receiving no treatment.

Group 2: Rats of this group received orally coca cola beverage $(5 \mathrm{ml} / \mathrm{Kg} /$ day $)$ by gastric tube for five months. 
Group 3: Rats of this group received orally coca cola beverage $(5 \mathrm{ml} / \mathrm{Kg} /$ day $)$ by gastric tube for seven months.

At the end of the experimental duration, all rats were placed individually in metabolic cages for $24 \mathrm{hr}$. Urine samples were collected, centrifuged and stored at $20^{\circ} \mathrm{C}$ until analysis. Overnight fasted rats were sacrificed under ether anesthesia. For biochemical analysis, blood samples were collected with no additives to obtain serum by centrifugation at $860 \mathrm{rpm}$. for 20 min. Thereafter, the right femur was separated and cleaned from the surrounding soft tissues. Then a small specimen of femur was weighed, crushed and homogenized in ice cold saline solution. The specimen was centrifuged for $20 \mathrm{~min}$. and the supernatant was separated for the biochemical assays. Meanwhile, the left femur was taken for subsequent determination of bone mineral density and water content.

\section{2-Analytical methods:}

Serum calcium and inorganic phosphorous levels were estimated by an atomic absorption spectrophotometer with an air acetylene flame following the method of Zettner and Seligson (1964). Creatinine level was determined using commercially available reagent Kits obtained from Randox Lab Ltd, U.K. Total protein content was determined according to the method described by Doumas (1975). The activity of the alkaline and acid phosphatase enzymes (ALP \& ACP) was determined using reagent Kits supplied by BioMerieux Laboratory Reagents and Products, France. Serum levels of calcitonine and parathyroid were measured using ELISA Germany Kits.

\section{3-Statistical analysis:}

All data were analyzed by one way analysis of variance (One-way ANOVA) followed by Least Significant Difference (LSD) test, using SPSS statistical package, version 17.00 software. The results were expressed as means \pm S.E and values were considered statistically significant at $\mathrm{p}<$ 0.05 (Snedecor and Cochran, 1982).

\section{RESULTS}

Data in table (1) recorded that the consumption of cola beverage for five or seven months induced significant increase in serum and urine calcium and inorganic phosphorus, with the decrease of these parameters in bone, a significant decrease in bone mineral density and a significant increase in femur water content. The data also recorded an increase in (ALP, ACP) activity in serum, urine, and bone in colatreated rats groups when compared to control group.

The data in table (2) showed an increase in serum and urine creatinine, creatinine ratio and urea, as well as a significant in- 
crease in parathyroid hormone level, while a decrease in serum total protein content and calcitonine hormone level were recorded in five and seven months of cola-consumption rat groups as compared with control group.

Table (1) : Serum, urine, and bone biochemical parameters in control, five and seven months coca cola consumption rat groups.

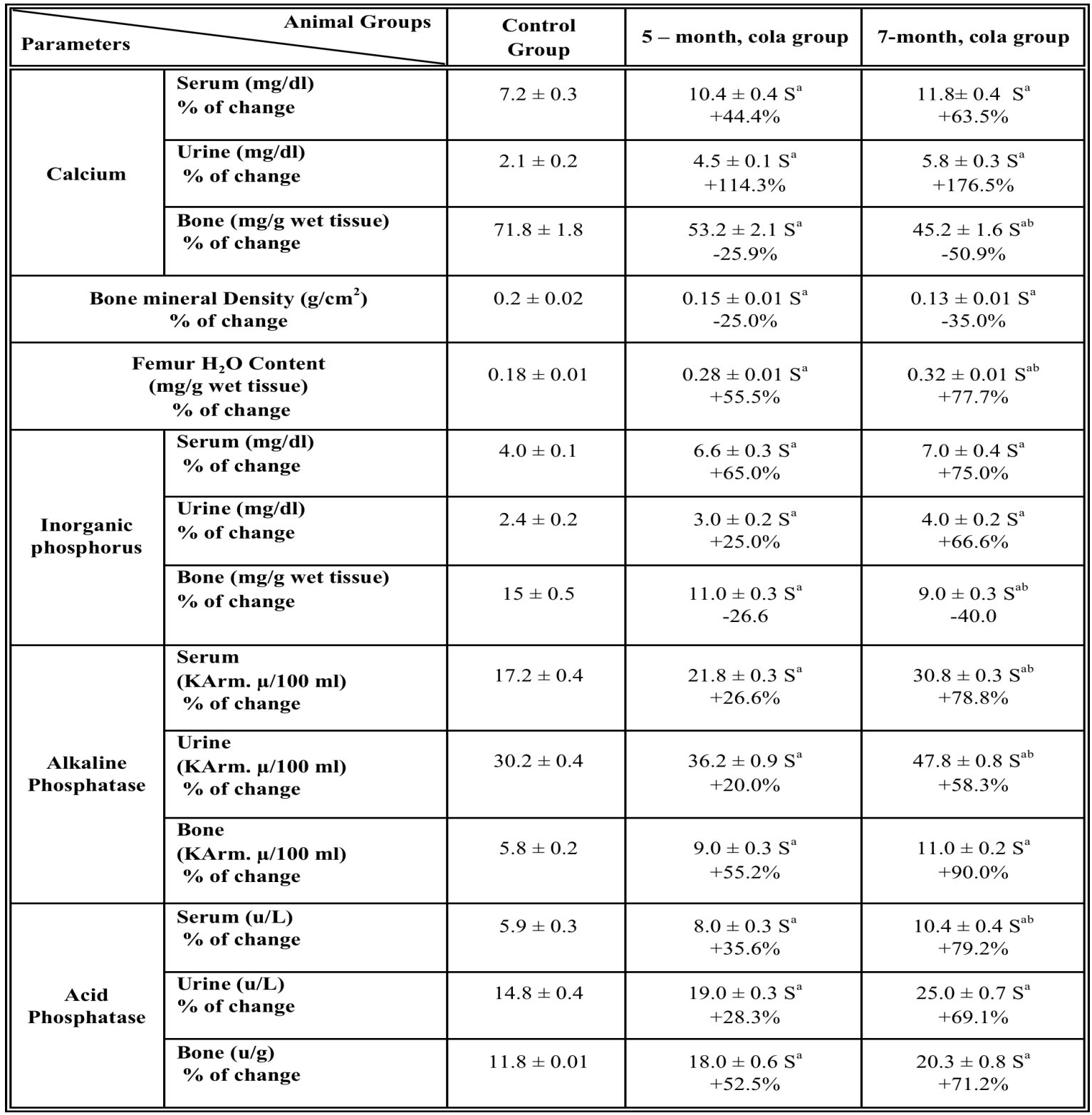

Data are expressed as means \pm S.E of six rats, $\%$ of change as compared to control group

$S^{a}$ : Significant in comparison with the control group $(\mathrm{P} \leq 0.05)$.

$\mathrm{S}^{\mathrm{b}}$ : Significant in comparison with the 5 months cola treated group $(\mathrm{P} 0 \leq 0.05)$ 
Table (2) : Serum and urine biochemical parameters in control, five and seven months coca cola consumption rat groups.

\begin{tabular}{|c|c|c|c|c|}
\hline \multicolumn{2}{|c|}{$\mathrm{P}_{\text {Parameters }}^{\text {Animal Groups }}$} & $\begin{array}{l}\text { Control } \\
\text { Group }\end{array}$ & $\begin{array}{c}5 \text { - month, cola } \\
\text { group }\end{array}$ & $\begin{array}{l}\text { 7-month, } \\
\text { cola group }\end{array}$ \\
\hline \multirow{2}{*}{ Creatinine mg/dl } & $\begin{array}{c}\text { Serum } \\
\% \text { of change }\end{array}$ & $2.1 \pm 0.2$ & $\begin{array}{l}2.3 \pm 0.06 \\
+9.5 \%\end{array}$ & $\begin{array}{c}2.5 \pm 0.08 \\
+19.0 \%\end{array}$ \\
\hline & $\begin{array}{c}\text { Urine } \\
\% \text { of change }\end{array}$ & $10.2 \pm 0.5$ & $\begin{array}{l}12.2 \pm 0.4 \\
+19.6 \%\end{array}$ & $\begin{array}{c}13.5 \pm 0.3 \mathrm{~S}^{\mathrm{a}} \\
+32.2 \%\end{array}$ \\
\hline \multirow{2}{*}{$\mathrm{Ca} /$ creatinine ratio } & $\begin{array}{c}\text { Serum } \\
\% \text { of change }\end{array}$ & $3.5 \pm 0.2$ & $\begin{array}{l}4.5 \pm 0.2 \mathrm{~S}^{\mathrm{a}} \\
\quad+28.8\end{array}$ & $\begin{array}{l}4.8 \pm 0.3 \mathrm{~S}^{\mathrm{a}} \\
\quad+37.1\end{array}$ \\
\hline & $\begin{array}{c}\text { Urine } \\
\% \text { of change }\end{array}$ & $0.2 \pm 0.03$ & $\begin{array}{c}0.36 \pm 0.02 \mathrm{~S}^{\mathrm{a}} \\
\quad+80.0 \%\end{array}$ & $\begin{array}{c}0.46 \pm 0.02 \mathrm{~S}^{\mathrm{a}} \\
+130.0 \%\end{array}$ \\
\hline \multirow{2}{*}{$\begin{array}{l}\text { Urea } \\
\text { mg/dl }\end{array}$} & $\begin{array}{c}\text { Serum } \\
\% \text { of change }\end{array}$ & $27.0 \pm 1.5$ & $\begin{array}{c}44.0 \pm 2.4 \mathrm{~S}^{\mathrm{a}} \\
+63.0 \%\end{array}$ & $\begin{array}{c}48.0 \pm 3.4 \mathrm{~S}^{\mathrm{a}} \\
+77.7 \%\end{array}$ \\
\hline & $\begin{array}{c}\text { Urine } \\
\% \text { of change }\end{array}$ & $9.0 \pm 0.3$ & $\begin{array}{l}11.0 \pm 0.7 \mathrm{~S}^{\mathrm{a}} \\
+22.2 \%\end{array}$ & $\begin{array}{c}12.8 \pm 0.4 \mathrm{~S}^{\mathrm{a}} \\
+42.2 \%\end{array}$ \\
\hline \multicolumn{2}{|c|}{$\begin{array}{l}\text { Serum total protein }(\mathrm{g} / \mathrm{dl}) \\
\% \text { of change }\end{array}$} & $7.1 \pm 0.3$ & $\begin{array}{c}6.8 \pm 0.4 \\
-4.2 \%\end{array}$ & $\begin{array}{c}5.8 \pm 0.2 \mathrm{~S}^{\mathrm{a}} \\
-18.3 \%\end{array}$ \\
\hline \multicolumn{2}{|c|}{$\begin{array}{l}\text { Parathyroid hormone }(\mathrm{pg} / \mathrm{ml}) \\
\% \text { of change }\end{array}$} & $20.2 \pm 0.8$ & $\begin{array}{c}33.2 \pm 0.9 \mathrm{~S}^{\mathrm{a}} \\
+64.3 \%\end{array}$ & $\begin{array}{c}38.4 \pm 0.9 \mathrm{~S}^{\mathrm{ab}} \\
+90.0 \%\end{array}$ \\
\hline \multicolumn{2}{|c|}{$\begin{array}{l}\text { Calcitonine hormone }(\mathrm{ng} / \mathrm{ml}) \\
\% \text { of change }\end{array}$} & $6.0 \pm 0.3$ & $\begin{array}{l}5.0 \pm 0.3 \\
-16.6 \%\end{array}$ & $\begin{array}{c}4.0 \pm 0.3 \mathrm{~S}^{\mathrm{a}} \\
-33.3 \%\end{array}$ \\
\hline
\end{tabular}

Data are expressed as means \pm S.E of six rats. \% of change as compared to control group $\mathrm{S}^{\mathrm{a}}$ : Significant in comparison with the control group $(\mathrm{P} \leq 0.05)$.

$S^{\text {b }}$ : Significant in comparison with the 5 months cola treated group $(P \leq 0.05)$

\section{DISCUSSION}

Osteoporosis is a skeletal disorder that is associated with lowered bone mineral density (BMD) and increased risk of fracture (Watts, 2002). Numerous dietary behaviors including excessive soft drink consumption have been found to be associated with low BMD and bone fractures (Tucker et al., 2006).
The present decrease in bone minerals (calcium and phosphorus) accompanied with an increase in their levels in serum and urine plays a major role in the genesis of coca-cola-associated bone loss. The association between bone metabolism disorders and cola beverage intake also has been attributed to some components of the cola beverage formulation, such as phosphoric acid, caffeine, sugar or aspartame 
or saccharin, caramel coloring, carbon dioxide, and aluminum. The phosphate content of soft drinks is very high, and they contain virtually no calcium (Vartanian et al., 2007). Acidifying dietary constituents may also negatively affect calcium metabolism and accelerate bone resorption (Buclin et al., 2001). Another possible mechanism underlying the effect on bone metabolism may be the acid load characteristic of cola drinks, which may adversely affect calcium and bone metabolism by increasing bone resorption and calcium mobilization and reducing the renal production of 25-hydroxyvitamin-D (Garcia et al., 2000). Furthermore, cola beverages are rich in caffeine which has been associated with reduced bone mineral density and increased fracture risk (Hernandez et al., 1993 and Ohta et al., 1999). Tucker et al. (2006) showed also that beverages with both phosphoric acid and caffeine increase urinary calcium excretion, and this may be the reason for reduced BMD. Moreover, Garcia et al. (2000) recorded subsequent hypocalcaemia and loss of femoral BMD in ovaryectomized rats received cola.

This study recorded a significant increase in serum, urine and bone alkaline and acid phosphatases activities after five or seven months of coca cola consumption. The results were in accordance with Hassan and El-Komy (2008). They reported that the long-term consumption of coca-cola caused an increase in bone resorption (as indicated by elevation of calcium/creatinine ratio and minerals excretion in urine) with resultant increase in the bone formation (as manifested by elevation of ALP activity in serum, urine, and bone). Coca-cola rich with caffeine, stimulate adrenal glands to secrete gluconeogenesis in the liver (Acheson et al., 2004) causing lipolysis in adipose tissue as well as rise in free fatty acids in the serum and futile recycling of triacyl glycerol, which could be responsible for the rise of glucose and triacyl glycerol in the serum and the increase in liver marker enzymes, ALT, AST, and ALP (Joseph and Kasinath, 2000).

$\mathrm{ACP}$ is an indicator of bone resorption, as this enzyme has been shown to be released from lysosomes in osteoclasts during bone resorption and hence triggers bone breakdown (Yang et al., 2001 and Bull et al., 2002). ACP generally showed an increased activity in bone diseases and physiological states with high bone resorption (Nakanishi et al., 1998). The present higher ACP activity in serum, urine, and bone in rats received coca-cola is consistent with those reports which suggested that the increase in ACP activity contributes to the mechanisms involved in the development of soft drinks-related bone loss (Jacobsson, 2008).

Data in this study recorded significant 
increase in serum and urine creatinine, urea as well as calcium/creatinine ratio, while the decrease was pronounced in the total protein. Creatinine is a waste product formed by protein metabolism; the major catabolic products and is excreted in the kidney. Urea is the main end product of protein catabolism. The serum creatinine level is used as an indicator of renal failure (Friday, 2004). Deluca (1981) reported that the renal dysfunction (as reflected by the increased serum creatinine level) was found to increase urinary minerals excretion with further increases in bone resorption. The occurred deficiency in bone minerals is apparently linked to the increase in the minerals excretion in urine and the rise in bone resorption (as measured by elevation in calcium/creatinine ratio, the marker of bone resolution (Ebeling et al., 1996) and the increase in serum level of calcium and phosphorus. Urea varies directly with protein intake and with the rate of excretion (Ranjna, 1999). A reduction in total protein content and elevation in creatinine level in serum of coca-cola treated rats may be attributed to the adverse effects of coca-cola on protein metabolism and kidney functions (Amato et al., 1998 and Ogor et al., 2007).

Significant increase in parathyroid hormone while a decrease in calcitonine hormone are recorded in the groups of rats administered coca cola for five or seven months. Parathyroid hormone is one of the most important hormones that regulate minerals' metabolism and act to increase bone breakdown or resorption by releasing calcium from bone and modulating differentiation of osteoblasts and osteoclasts (Munnstadt et al., 1999). Different factors are thought to be involved in the observed development of hyper-parathyroidism recorded in the present study. These factors include kidney dysfunction which seemed in the present study by an increase in serum creatinine level and defective calcium absorption mechanisms (Zung and Chalw, 1997). Also, these factors are known to cause a negative calcium balance, and are thus frequently associated with a compensatory rise in $\mathrm{PTH}$, which in turn enhances calcium release from the skeleton causing bone loss (Guillemant et al., 1999). Other observations demonstrated that the diets high in phosphorus could be deleterious to bone through the increased PTH secretion in rats (Huttunen et al., 2006 and Kemi1 et al., 2006). The present increase in parathyroid hormone and renal dysfunction (as indicated by increased creatinine level) may provide a partial explanation for the negative effects of coca-cola on bone health as has been reported by Ogor et al. (2007) who suggested that the decrease in bone minerals density might be related to the renal damage. Among the po- 
tentially deleterious constituents, phosphoric acid can reduce 25-dihydroxy vitamin-D synthesis, interfere with intestinal absorption and interfere with renal reabsorption of calcium leading to hypocalcaemia and causing secondary hyperparathyroidism which appears insufficient to revert to a low calcium plasma level (Guerreroet al., 1999 and Garcia et al., 2000).

Calcitonine is less important than PTH in regulating serum calcium, where it acts as a physiological antagonist to PTH (Yasutomo and Nagata, 1992). Its main physiological role is to control hypocalcaemia and inhibits bone resorption by acting directly on osteoclasts, where it binds to high affinity osteoclastic receptors and inhibits osteoclastic activity (Colman et al., 2002). The deficiency in calcitonine observed in the present work may be attributed to the changes induced in serum calcium level.

\section{CONCLUSION}

It can be concluded that the prolonged consumption of coca cola beverage for five or seven months results in osteoporosis as indicated by a marked disturbance in bone markers associated with bone loss. In addition, the seven months consumption shwed more pronounced effects than the five month, so we must avoid the excess of these drinks.

\section{REFERENCES}

Achecon, K. J.; Fay, L. M. and Schindler, C. (2004): "Metabolic effects of caffeine in humans". Am. J. Clin. Nutr., 79:40.

Amato, D.; Maravilla, A.; Montoya, C.; et al. (1998): "Acute effects of soft drink intake on calcium and phosphate metabolism in immature and adult rats". Rev. Invest. Clin., 50(3):185-189.

Bassiouny, M. A. and Yang, J. (2005): "Influence of drinking patterns carbonated beverages on dental erosion". General Dentistry, 53: 3-12.

Bobbi, A.; Augusti, K. T. and Joseph, P. K. (1984): "Effects of alcohol consumption on levels of serum marker enzymes". Indian J. Biochem. Biophys., 21:211.

Buclin,T.; Cosma, M.; Appenzeller, A. F.; et al. (2001): "Diet acids and alkalis influence calcium retention in bone Osteoporos". Int. J., 12 (6): 493-499.

Bull, H.; Murray, P. G. and Thomas, D. (2002): "Acid phosphates." Mol. Biol., 55: 65-72.

Colman, F.; Hedin, R.; Swann, J. and Orloff, D. (2002): "A brief history of calcitonine". Lancet, 359: 885-886.

Doumas, B. T. (1975): "Colorimetric de- 
termination of total protein based on the Biuret method". Clin. Chem., 21: 11591166.

Ebeling, P. R.; Altey, L. M. and Guthrie, J. R. (1996): "Bone turnover markers and bone density across the menopausal transition". J. Clin. Endocrinol. Metab., 81: 3366-3371.

Friday, E.U. (2004): Clinical uses of enzymes In: Conceptual Enzymology, Innolex Printers and Publishers, Calabar, PP. 190-212.

Garcia-Contreras, F.; Paniagua, R. and Avila-Diaz, M. (2000): "Cola beverage consumption induces bone mineralization reduction in ovariectomizedrats". Arch. Med. Res., 31(4):360-365.

Gartland, C.; Robson, P.J. and Murray, L. (2003): "Carbonated soft drink consumption and bone mineral density in adolescence: the Northern Ireland Young Hearts project". J. Bone Miner. Res., 18:1563-1569.

Goulding, A. (2007): "Risk factors for fractures in normally activechildren andadolescents". Med. Sport. Sci., 51:102-120.

\section{Guerrero-Romero, F.; Rodriguez-} Moran, M. and Reyes, E. (1999): "Consumption of soft drinks with phosphoric acid as a risk factor for the development of hypocalcaemia in postmenopausal women". J. Clin. Epidemiol., 52(10): 1007-1010.

Guillemant, J.; Le, H. T. and Maria, A. (1999): "Acute effects of oral calcium load on parathyroid function and on bone desorption in young men". Am. J. Nephrol., 20: $48-52$.

Hassan, H. A. and El-Komy, M. M. (2008): "Long - term consumption of cola beverage and osteoporosis markers relationship in female albino rats". Egypt. J. Zool., 51:331-344.

Hernández-Avila, M.; Stampfer, M. J.; Ravnikar, V.A.; et al. (1993): "Caffeine and other predictors of bone density among perimenopausal women". Epidemiology, 4(6):128-13.

Huttunen, M.; Pietila, P.; Viljakainen, H. and Lamberg-Allardt, C. (2006): "Prolonged increase in dietary phosphate intake retards bone dietary $\mathrm{P}$ and bone 551 mineralization in adult male rats". J. Nutr. Biochem., 17: 479-484.

Jacobsson, H. (2008): "Short-time ingestion of colas influences the activity distribution at bone scintigraphy: Experimental studies in the mouse". J. Am. College Nutr., 27(2): 332-336.

James, J.; Thomas, P. and Cavan, D. (2004): "Preventing childhood obesity by 
reducing consumption of carbonated drinks: Cluster randomized controlled trial". BMJ, 328:1237.

Jean, P. and Murray, L. (2003): "Cola consumption and low bone mineral density in women". J. Bone Minor Res. 18: 15631572.

Joseph, P. K. and Kasinath, R. T. (2000): "Hypoglycemic and hypolipidemic effects of diaceto-dibutyl-disulphide". Indian J. Biochem, 15:68-75.

Kanis, J. (1994): WHO Study Group. Assessment of fracture risk and its applications to screening for postmenopausal osteoporosis of a WHO report. Osteoporosis Int.4:368-381.

Kemi, V. E.; Merja, U.; Karkkainen1, M.; et al. (2006): "High phosphorus intakes acutely and negatively affect $\mathrm{Ca}$ and bone metabolism in a dose-dependent manner in healthy young females". Br. J. Nutr., 96: 545-552.

Kondal,A. and Garg, S.K. (2003): "Influence of acidic beverage (coca-cola) on pharmacokinetics ibuprofen in healthy rabbits". Ind. J. Exp. Biol., 41(11):13221324.

Milne, D.B. and Nielsen, F. H. (2000): "The interaction between dietary fructose andmagnesium adversely affects macro mineral homeostasis in men". J. Am. Coll. Nutr., 19:31-37.

Munnstadt, M.; Juppner, H. and Gardella, T. J. (1999): "Receptors for PTH and PTHrp: their biological importance and functional properties". Am. J. Physiol., 277: 665-675.

Nakanishi, M.; Yoh, K. and Uchida, K. (1998): "Improved method for measuring tartarate resistant acid phosphates activity in serum". Clin. Chem., 44: 221225.

Ogor, R.; Uyall, B.;Ogur, T.; et al. (2007): "Evaluation of the effect of cola drinks on bone mineral density and associated factors". Basic Clini. Pharmacol. Toxicol., 100: 334-338.

Ohta, M.; Cheuk, G.; Thomas, K.; et al. (1999): "Effect of caffeine on the bones of aged ovariectomized rats". Ann. Nutr. Metab., 43 (1):52-59.

Ranjna, C. (1999): Practical clinical biochemistry methods and interpretation, $2^{\text {nd }}$ edition. P. 117.

Rapuri, P.B.; Gallagher, J.C.; Kinyamu, H.K. and Ryschon, K. L. (2001): "Caffeine intake increases the rate of bone loss in elderly women and interacts with vitamin D receptor genotypes". Am. J. Clin. Nutr., 74:694-700. 
Root, A. W. (2002): "Bone strength and the adolescent". Adolesc. Med., 13(1):5372 .

Snedecor, C. W. and Cochran, W. C. (1982): Statistical Methods. $7^{\text {th }}$ edition. The State University Press American, Iowa. P. 593.

Tucker, K. L. (2003): "Dietary intake and bone status with aging". Curr. Pharm. Des., 9: 2687-2704.

Tucker, K. L.; Morita, K.; Qiao, N.; et al. (2006): "Colas, but not other carbonated beverages, are associated with low bone mineral density in older women: The Framingham Osteoporosis Study". Am. J. Clin. Nutr., 84(4): 936-942.

Vartanian, L. R.; Schwartz, M. B. and Brownell K. D. (2007): "Effects of soft drink consumption on nutrition and health: a systematic review and metaanalysis". Am. J. Public Health, 97: 667-675.

Watts, N. B. (2002): "Therapies to improve bone mineral density and reduce the risk of fracture: clinical trial results". J. Reprod. Med., 47(1): 82-92.

Whiting, S. J.; Healey, A.; Psiuk, S.; et al. (2001): "Relationship between carbonated and other low nutrient dense beverages and bone mineral content of adolescents". Nutr. Res., 21:1107-1115.

Wyshak, G. (2000): "Teenaged girls, carbonated beverage consumption, and bone fractures". Arch. Pediatr. Adolesc. Med., 154:610 -613.

Wyshak, G. and Frisch, R. F. (1994): "Carbonated beverages, dietary calcium, the dietary calcium/phosphorus ratio, and bone fractures ingirls and boys". J. Adolesc. Health, 15(3): 210-215.

Yang, S., Mdyastha, P. and Bingel, S. K. (2001): "A new superoxide-generating oxidase in murine osteoclasts". Biochem. Mol. Biol. Int., 276(8): 5452-5458.

Yasutomo, Y. and Nagata, N. (1992): "Parathyroid hormone and calcitonin". Nippon Rinsho., 50(12): 2925-2930.

Zettner, A. and Seligson, D. (1964): "Application of atomic absorption spectrophotomtery in the determination of calcium in serum". Clin. Chem., 10:869-890.

Zung, A. and Chalw, S. A. (1997): "Effect of age on the response to parathyroid hormone". Metabolism, 46(11): 1246-1251. 


\section{العلاقة بين الإصابة بهشاشة العظام

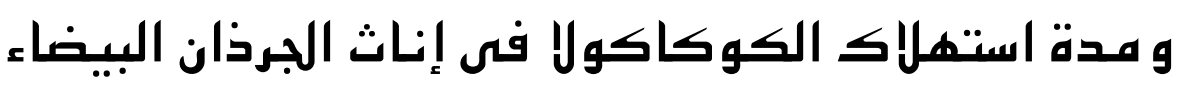 \\ المشتركون فى البحث}

هنـاء هـمـــ سـراج

قسم علم الحيوان- كلية العلوم- جامعة المنصورة- مصر

تناول الكوكاكولا من العوامل المسببة لنقص الكالسيوم وزيادة خطر الإصابة بهشاشة العظام في الجرذان. ولذا كان الهدف من هذه الدراسة هو المقارنة بين التناول لمدة خمسة أشهر وسبعة أشهر وعلاقة المدة على مستوى دلالات هشاشه العظام.

وقد أسفرت نتائج البحث عن أن تناول الكوكاكولا بـجرعة يومية قدرها ممل/كجم من وزن الجسم لمدة خمس أو سبع أشهر كان سببا في الزيادة الملحوظة في مستوى الكالسيوم والفسفور في كل من السيرم والبول مصحوبا بنقصهما في العظام وخاصة لمجموعة السبعة أشهر من تناول الكوكاكولا. وفي نفس الوقت كانت الزيادة أيضا في السيرم والبول من الكرياتينين واليوريا ومستوى هرمون الغدة الجار درقية ولكن النقص كان واضحا في مستوى هرمون الكالسيتونين ومحتوى المصل من البروتين الكلي .

كما أوضحت الدراسة ارتفاعا في مستوى نشاط إنزيي الفوسفاتيز الحامضي والقاعدي في كل من المصل والبول والعظام وزيادة في محتوى

الماء بعظمة الفخذ مع انخفاض في كثافة العظم من المعادن. كل هذه المعايير كانت أكثر حدة وظهوراً في المجموعة المعاملة لمدة سبعة أشهر. ولذا من الممكن أن نستخلص أن تناول الكوكاكولا على المدى البعيد قد يؤدي إلى الإصابة بهشاشة العظام نتيجة الخلل الحادث في مستوى دلالات هشاشة العظام التي سبق الإشارة إليها . 